\begin{tabular}{|c|c|c|c|}
\hline \multirow{3}{*}{$\begin{array}{r}\text { Case Reports in } \\
\text { Gastroenterology }\end{array}$} & \multicolumn{2}{|c|}{ Case Rep Gastroenterol 2016;10:275-282 } & \multirow[b]{2}{*}{$\begin{array}{l}\text { Karger } \\
\text { Open access }\end{array}$} \\
\hline & $\begin{array}{l}\text { DOI: 10.1159/000446579 } \\
\text { Published online: June 14, } 2016\end{array}$ & $\begin{array}{l}\text { ( } 2016 \text { The Author(s) } \\
\text { Published by S. Karger AG, Basel } \\
\text { www.karger.com/crg }\end{array}$ & \\
\hline & $\begin{array}{l}\text { This article is licensed under } \\
\text { International License (CC BY-N } \\
\text { Usage and distribution for comm }\end{array}$ & $\begin{array}{l}\text { nons Attribution-NonCommercial } 4.0 \\
\text { ger.com/Services/OpenAccessLicense) } \\
\text { uires written permission. }\end{array}$ & \\
\hline
\end{tabular}

\title{
Unusual False-Positive Mesenteric Lymph Nodes Detected by PET/CT in a Metastatic Survey of Lung Cancer
}

\author{
Hirohiko Kamiyama ${ }^{a}$ Kazuhiro Sakamoto ${ }^{a} \quad K^{\prime}$ oichiro Niwa ${ }^{a}$ \\ Shun Ishiyama ${ }^{a}$ Makoto Takahashi ${ }^{a}$ Yutaka Kojima $^{a}$ Michitoshi Goto $^{a}$ \\ Yuichi Tomiki $^{\mathrm{a}}$ Itsuko Nakamichi ${ }^{\mathrm{b}}$ Shiaki Oh ${ }^{\mathrm{c}}$ Kenji Suzuki $^{\mathrm{c}}$ \\ ${ }^{a}$ Department of Coloproctological Surgery, Juntendo University School of Medicine, \\ Tokyo, Japan; ${ }^{b}$ Department of Human Anatomical Pathology, Juntendo University School \\ of Medicine, Tokyo, Japan; 'Department of General Thoracic Surgery, Juntendo University \\ School of Medicine, Tokyo, Japan
}

\section{Keywords}

False positivity $\cdot$ Positron emission tomography $\cdot$ Non-small cell lung cancer $\cdot$ Lymph node

\begin{abstract}
Positron emission tomography/computed tomography (PET/CT) is a credible diagnostic modality for detecting primary and metastatic malignancy. PET/CT sometimes shows false positives and negatives, which make clinical diagnosis difficult. A 42-year-old man who had undergone right upper lobectomy for lung cancer 1 year previously had PET/CT for a metastatic survey of the lung. The lung cancer was stage IB (pT2NOM0) bronchioloalveolar carcinoma. PET/CT showed massive ${ }^{18} \mathrm{~F}$-fluorodeoxyglucose (FDG) uptake in the mesenteric lymph nodes. Because the mesentery is an unusual site of metastasis, the patient was under watchful observation. Another PET/CT after 6 months still showed FDG uptake in the same location, with a slightly increased standard uptake value. A systemic survey was performed, but it did not reveal any malignancies or inflammatory diseases. Eventually, the patient underwent probing laparoscopic surgery. For complete resection of the lymph nodes, laparoscopic ileocecal resection was performed. Histologically, the resected lymph nodes showed reactive lymphadenitis. Glucose transporter 1 immunostainings of the lung cancer and the lymph
\end{abstract}




\section{Case Reports in Gastroenterology}

Case Rep Gastroenterol 2016;10:275-282 $10.1159 / 000446579$

(c) 2016 The Author(s). Published by S. Karger AG, Basel www.karger.com/crg

Kamiyama et al.: Unusual False-Positive Mesenteric Lymph Nodes Detected by PET/CT in a Metastatic Survey of Lung Cancer

node were positive and partially positive, respectively. Although PET/CT is a powerful diagnostic modality, clinical interpretation of unusual results is difficult.

(C) 2016 The Author(s)

Published by S. Karger AG, Basel

\section{Introduction}

Positron emission tomography/computed tomography (PET/CT) is a credible diagnostic modality for detecting primary and metastatic malignancy. The first commercial PET/CT scanner appeared in early 2001, and currently over 2,000 PET/CT scanners are operational worldwide [1]. Because PET/CT allows whole body scanning in a single series, it is best suitable for the staging and metastatic survey of cancer. On the other hand, it is not the best diagnostic modality for detecting early cancer, because it is difficult to detect small lesions or lesions with low glycometabolism. In addition, PET/CT shows false positives and negatives. The ability of PET to identify tumors depends primarily on the degree of $18 \mathrm{~F}$-fluorodeoxyglucose (FDG) uptake by malignant cells, the size of the tumor, and the presence or absence of inflammation [2]. A prospective study comparing the ability of PET and other modalities, including CT, ultrasonography, bone scanning, and needle biopsy, revealed that PET improved the rate of detection of mediastinal lymph nodes and distant metastasis in patients with non-small cell lung cancer [2]. The false-positive and false-negative rates of lymph nodes in lung cancer for PET were reported to be 8 and 13\%, respectively [3]. Integrated PET/CT was significantly better than CT alone in lung cancer staging. However, there was still a false-positive rate of $16 \%$ for lymph nodes on integrated PET/CT, while the corresponding value for CT alone was $31 \%$ [4].

Here we report an atypical case of false-positive mesenteric lymph nodes on PET/CT for a metastatic survey after surgery of lung cancer. The mesenteric lymph nodes are unusual sites of metastasis in lung cancer. However, the high avidity on PET/CT persisted for as long as 6 months in the present case, which caused us to consider biopsying the lesion.

\section{Case Report}

A 42-year-old man underwent PET/CT for a metastatic survey 1 year after right upper lobectomy for lung cancer. His lung cancer was a well-differentiated bronchioloalveolar carcinoma of the mucinous type, $9.0 \times 7.9 \times 3.9 \mathrm{~cm}$ in size, and the pathological stage was IB (pT2N0M0, 6th edition of UICC TNM staging, P0, ly0, v0, br-, $\mathrm{n}=0 / 29$ ). The PET/CT before his lung surgery had shown faint avidity [max. standard uptake value (SUV) $=2.1$ ] in the primary lesion with no locoregional and distant metastasis (fig. 1). In the postoperative course of the lung cancer, he had chylothorax, and OK-432 was injected into the right thoracic cavity on the 3rd postoperative day to achieve pleurodesis. He had taken oral uracil and tegafur after the surgery as an adjuvant chemotherapy. The PET/CT 1 year after the lung surgery showed massive FDG uptake (max. SUV $=4.9$ ) and enlargement in the mesenteric lymph nodes on the ileocecal artery which had not been detected on PET/CT at the time of diagnosis of lung cancer (fig. 2). He did not have any abdominal symptoms, and tumor markers were negative except for a slight increase in pro-gastrin-releasing peptide $(46.5 \mathrm{pg} / \mathrm{ml})$. We decided to watch the patient carefully for 6 months without any change of treatment, since mesenteric lymph nodes are not usual for metastasis of lung cancer and there was no other evidence which strongly suggested any relapse of the tumor. Another PET/CT was 
conducted 6 months afterwards, and it showed uptake in the same lesion with an increased SUV (max. SUV = 6.7) (fig. 3). Due to this persistently high avidity in the mesenteric lymph nodes, a systemic survey for malignancy was conducted to rule out lymph node metastasis of the primary lung cancer or malignancy of another origin. Colonoscopy, esophagogastroduodenoscopy, double-balloon enteroscopy, and bone marrow biopsy were performed, but there was no problem. Therefore, we decided to biopsy the lymph nodes surgically. By appropriate informed consent, the patient underwent probing laparoscopic surgery for these mesenteric lymph nodes.

In the operation, several enlarged mesenteric lymph nodes along the ileocecal artery were found, and four samples from those lymph nodes on the proximal and distal ileocecal artery were negative for tumor at intraoperative frozen-section diagnosis. For complete and safe resection of all other enlarged lymph nodes, laparoscopic ileocecal resection was performed. The postoperative course was uneventful, and the patient was discharged on the 12 th postoperative day.

A total of 26 lymph nodes alongside the ileocecal artery were harvested. The maximum size of the lymph nodes was $8 \mathrm{~mm}$. Microscopically, there was a relatively increased number of lymph nodules with a mature germinal center in each lymph node; however, the basic structure of the lymph nodes, such as the lymphatic sinus, hilum, and cortex, stayed normal. Histologically, these lymph nodes showed reactive lymphadenitis, and there was no evidence of malignancy (fig. 4).

PET/CT performed 1 year after the ileocecal resection showed no abnormal avidity anywhere (figure not shown). The patient has been disease free for 6 years since the surgery of his lung cancer.

\section{Discussion}

Possible conditions of the lymph nodes of the lung which could show false positivity on PET include lymphadenitis, reactive hyperplasia, histoplasmosis, tuberculosis, fungal infection, sarcoid reaction, anthracotic and anthracosilicotic spindle cell proliferation, and asbestosis [3]. The healing process leads to an inflammatory reaction with leukocytic infiltration into the granulation tissue even in the absence of infection, and it could also result in falsepositive results [5]. One study suggested that a larger cutoff SUV be set to reduce the falsepositive rate, and to use different cutoff values for each nodal station in mediastinal lymph nodes, since the SUV varies widely by location [6]. Another study suggested that imaging modalities more delayed than conventional PET could distinguish malignancies from benign lesions more accurately [7].

The cutoff for the maximum SUV varies between each organ, and that for lung cancer is 2.5 in general. The maximum SUVs for the lymph nodes in the present case were significantly higher than that. On the other hand, the avidity of FDG in lung cancer varies by histological type, and bronchioloalveolar carcinoma has been suggested to be lucent on PET [8]. In fact, the maximum SUV for the lung cancer in the present case was as low as 2.1. Therefore, PET might not have been suitable for surveying the bronchioloalveolar carcinoma.

Lymphoid follicular hyperplasia with glucose transporter 1 (Glut1) overexpression is suggested to have a causal relationship to high FDG uptake, which might result in false positives [9]. There was a study showing that both Glut1 expression and FDG uptake were significantly lower in bronchioloalveolar carcinoma than in other histological types of non-small cell lung cancer [10]. However, Glut1 immunostaining in the present case showed positivity 
with high intensity in the lung cancer and partial positivity with low intensity in the mesenteric lymph nodes (fig. 5).

The reason for the reactive lymphadenitis in the present case still remains unclear. One possibility is that lymphadenitis had developed via insignificant enteritis; however, this is unlikely to last for 6 months. We suspect that the pleurodesis achieved with OK-432 might have affected the lymphatic flow of the patient, which resulted in mesenteric lymphadenitis. Ileocecal resection might have been an overtreatment; however, we did not want to leave residual lesions.

PET allows for improved staging of non-small cell lung cancer, but false positives might lead to unnecessary mediastinoscopy [11]. On the other hand, in one study the false-negative results on PET did not affect the therapeutic strategy but paradoxically benefited patients by preventing them from unnecessary invasive thoracotomy, mediastinoscopy, or other sampling procedures [3]. It is difficult to interpret false-positive results on PET, which is why other modalities with fewer false positives and false negatives are still needed.

\section{Acknowledgement}

The authors would like to thank Dr. Hiroyuki Mitomi for his pathological diagnoses and helpful comments.

\section{Statement of Ethics}

The authors have no ethical conflicts to disclose.

\section{Disclosure Statement}

H. Kamiyama and co-authors have no conflict of interest to declare.

\section{References}

1 Townsend DW: Combined positron emission tomography-computed tomography: the historical perspective. Semin Ultrasound CT MR 2008;29:232-235.

2 Pieterman RM, van Putten JW, Meuzelaar JJ, Mooyaart EL, Vaalburg W, Koeter GH, et al: Preoperative staging of non-small-cell lung cancer with positron-emission tomography. N Engl J Med 2000;343:254261.

3 Gupta NC, Tamim WJ, Graeber GG, Bishop HA, Hobbs GR: Mediastinal lymph node sampling following positron emission tomography with fluorodeoxyglucose imaging in lung cancer staging. Chest 2001;120:521-527.

4 Shim SS, Lee KS, Kim BT, Chung MJ, Lee EJ, Han J, et al: Non-small cell lung cancer: prospective comparison of integrated FDG PET/CT and CT alone for preoperative staging. Radiology 2005;236:1011-1019.

5 Rosenbaum SJ, Lind T, Antoch G, Bockisch A: False-positive FDG PET uptake - the role of PET/CT. Eur Radiol 2006;16:1054-1065.

6 Bryant AS, Cerfolio RJ, Klemm KM, Ojha B: Maximum standard uptake value of mediastinal lymph nodes on integrated FDG-PET-CT predicts pathology in patients with non-small cell lung cancer. Ann Thorac Surg 2006;82:417-422; discussion 422-423.

7 Kubota K, Itoh M, Ozaki K, Ono S, Tashiro M, Yamaguchi K, et al: Advantage of delayed whole-body FDGPET imaging for tumour detection. Eur J Nucl Med 2001;28:696-703. 


\section{Case Reports in Gastroenterology}

\begin{tabular}{l|l}
\hline Case Rep Gastroenterol 2016;10:275-282 \\
\hline $10.1159 / 000446579$ & $\begin{array}{l}\text { @ 2016 The Author(s). Published by S. Karger AG, Basel } \\
\text { www.karger.com/crg }\end{array}$ \\
\hline
\end{tabular}

Kamiyama et al.: Unusual False-Positive Mesenteric Lymph Nodes Detected by PET/CT in a Metastatic Survey of Lung Cancer

8 Higashi K, Nishikawa T, Seki H, Oguchi M, Nambu Y, Ueda Y, et al: Comparison of fluorine-18-FDG PET and thallium-201 SPECT in evaluation of lung cancer. J Nucl Med 1998;39:9-15.

9 Chung JH, Cho KJ, Lee SS, Baek HJ, Park JH, Cheon GJ, et al: Overexpression of Glut1 in lymphoid follicles correlates with false-positive ${ }^{18 F-F D G ~ P E T ~ r e s u l t s ~ i n ~ l u n g ~ c a n c e r ~ s t a g i n g . ~ J ~ N u c l ~ M e d ~ 2004 ; 45: 999-~}$ 1003.

10 Higashi K, Ueda Y, Sakurai A, Wang XM, Xu L, Murakami M, et al: Correlation of Glut-1 glucose transporter expression with [18F]-FDG uptake in non-small lung cancer [sic!]. Eur J Nucl Med 2000;27:1778-1785.

11 Cerfolio RJ, Ojha B, Bryant AS, Bass CS, Bartalucci AA, Mountz JM: The role of FDG-PET scan in staging patients with nonsmall cell carcinoma. Ann Thorac Surg 2003;76:861-866.
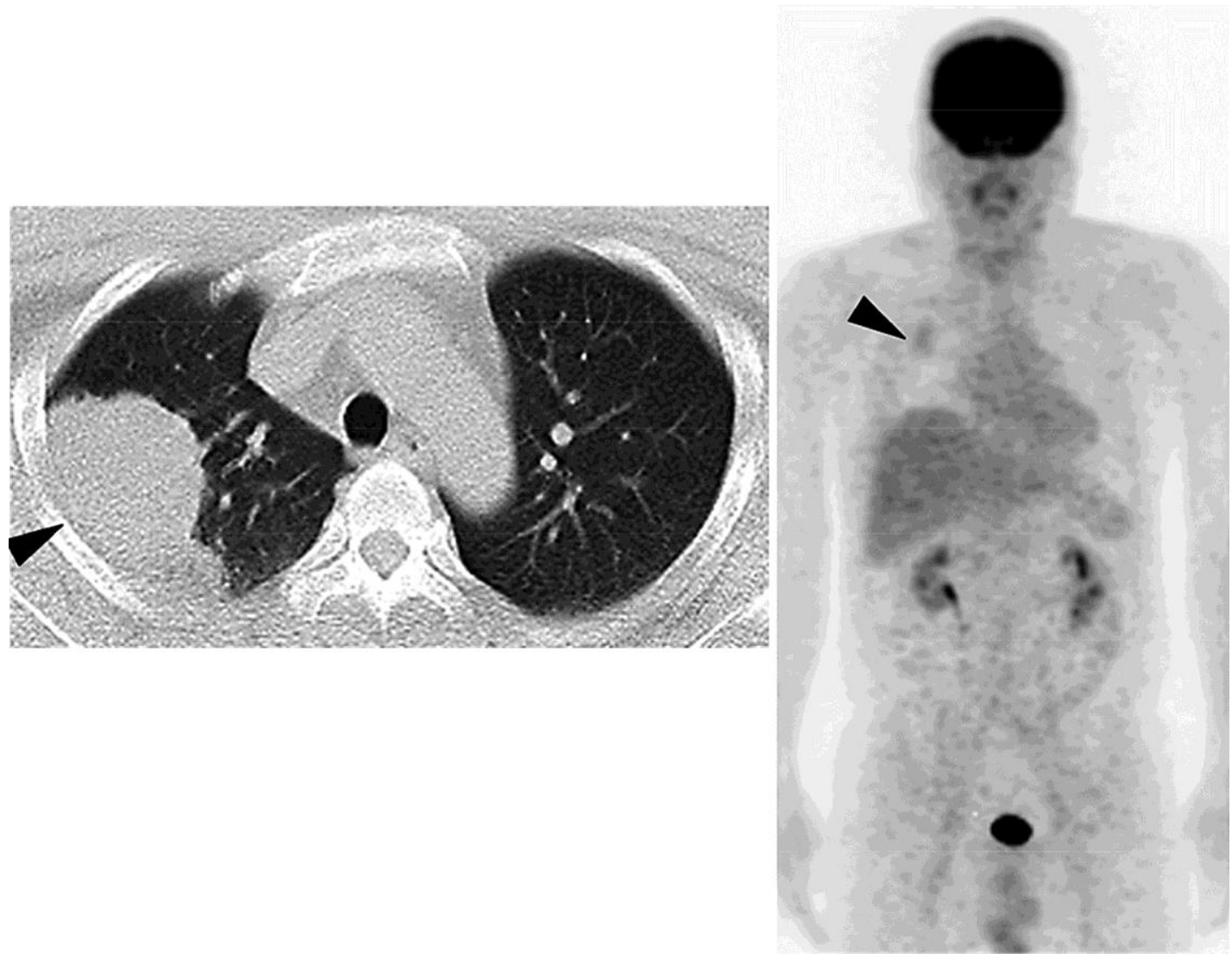

Fig. 1. PET/CT before lung surgery revealing a lung tumor with faint avidity of FDG in the right lung (arrowheads). 


\begin{tabular}{|c|c|c|}
\hline \multirow{3}{*}{$\begin{array}{r}\text { Case Reports in } \\
\text { Gastroenterology }\end{array}$} & \multirow{2}{*}{\multicolumn{2}{|c|}{ Case Rep Gastroenterol 2016;10:275-282 }} \\
\hline & & \\
\hline & $10.1159 / 000446579$ & $\begin{array}{l}\text { (c) } 2016 \text { The Author(s). Published by S. Karger AG, Basel } \\
\text { www.karger.com/crg }\end{array}$ \\
\hline
\end{tabular}
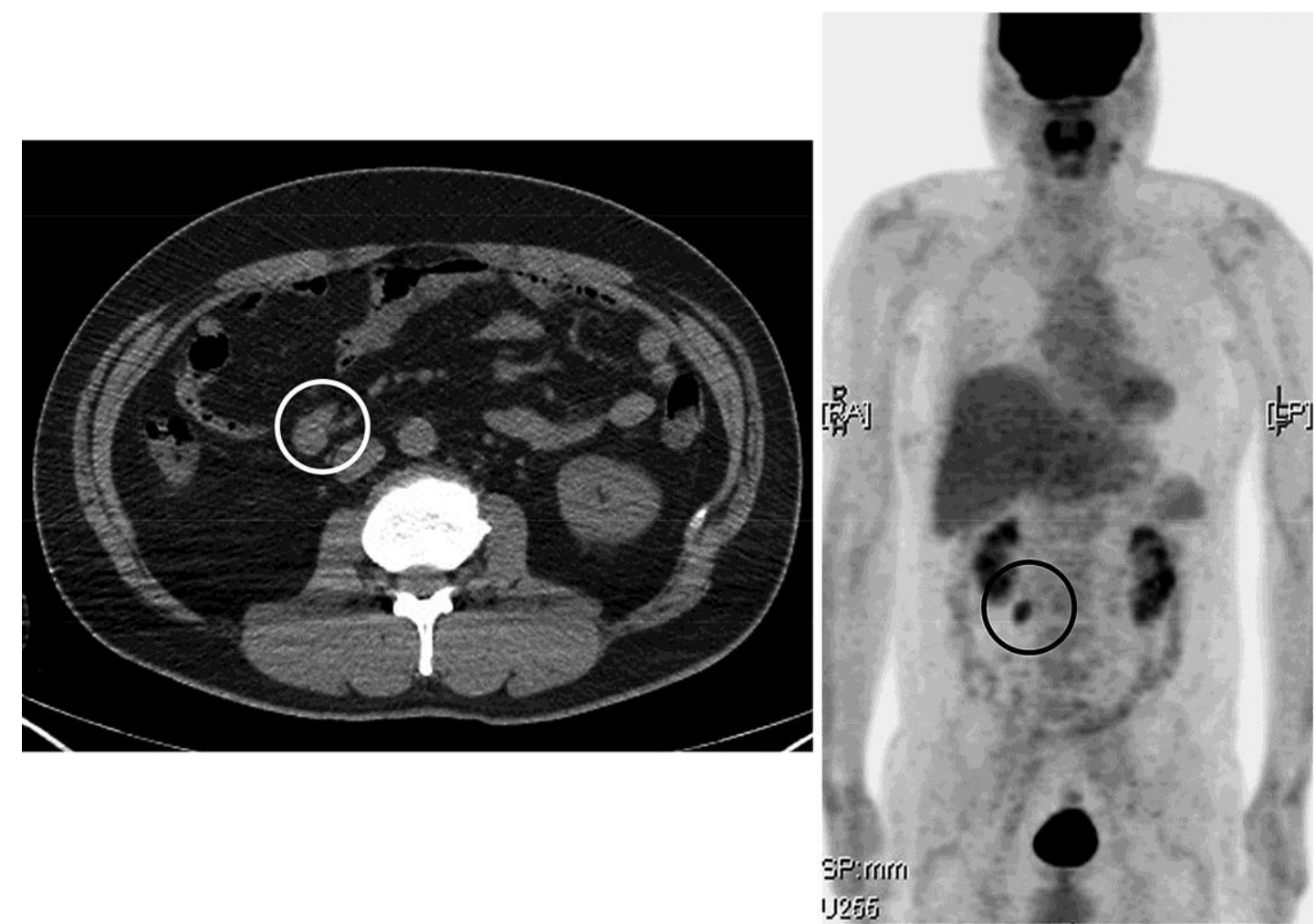

Fig. 2. PET/CT 1 year after pulmonary surgery showing massive FDG uptake in the mesenteric lymph nodes along the ileocecal artery (circled). 


\section{Case Reports in Gastroenterology}

\begin{tabular}{l|l}
\hline Case Rep Gastroenterol 2016;10:275-282 \\
\hline $10.1159 / 000446579$ & $\begin{array}{l}\text { @ 2016 The Author(s). Published by S. Karger AG, Basel } \\
\text { www.karger.com/crg }\end{array}$ \\
\hline
\end{tabular}

Kamiyama et al.: Unusual False-Positive Mesenteric Lymph Nodes Detected by PET/CT in a Metastatic Survey of Lung Cancer

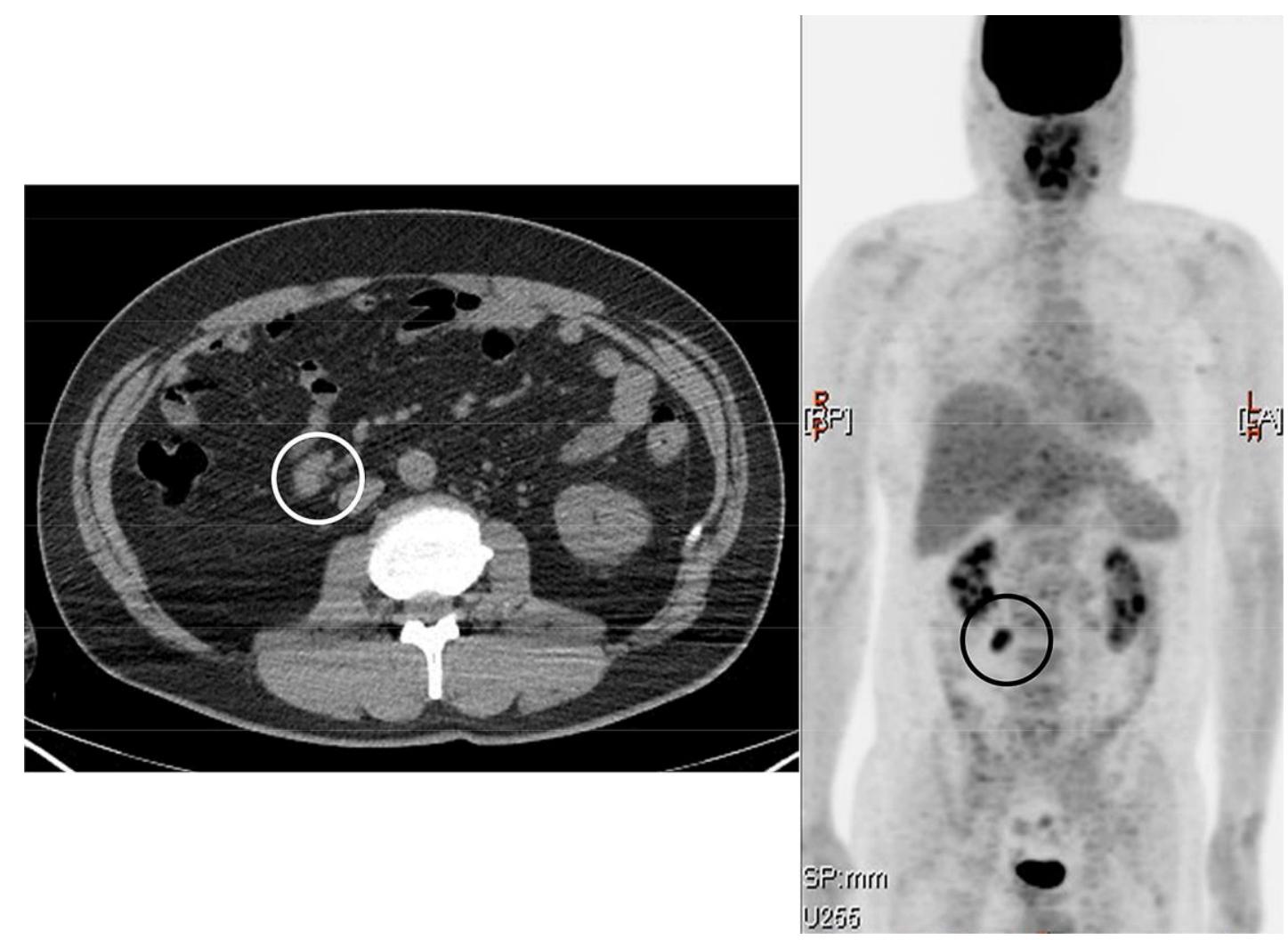

Fig. 3. PET/CT 6 months after figure 2 showing FDG uptake in the same lesion with a slightly increased SUV (circled).

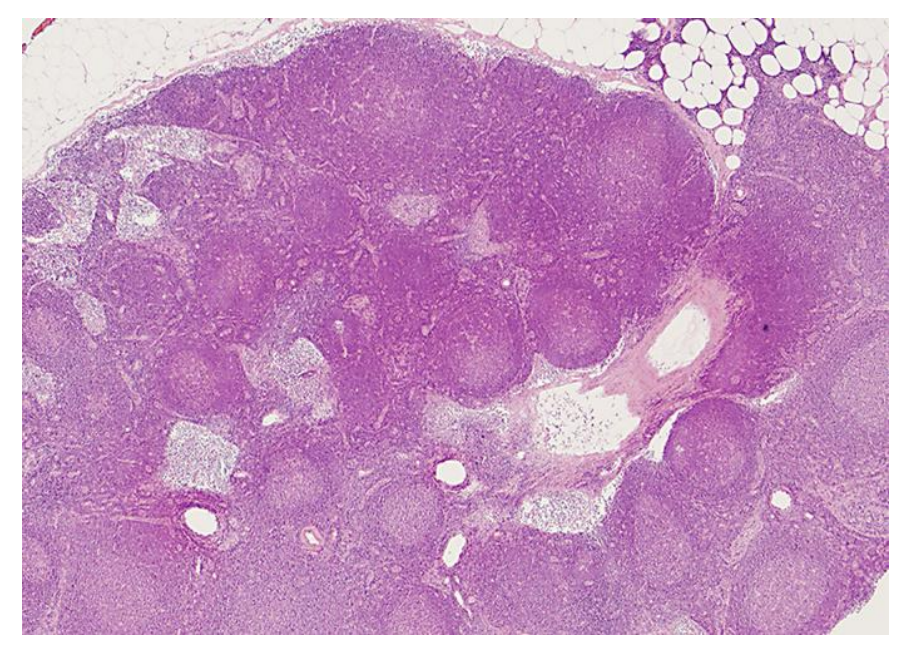

Fig. 4. Resected lymph nodes showing reactive lymphadenitis. HE. $\times 10$. 


\section{Case Reports in Gastroenterology}

\begin{tabular}{l|l}
\hline Case Rep Gastroenterol 2016;10:275-282 \\
\hline $10.1159 / 000446579$ & $\begin{array}{l}\text { C 2016 The Author(s). Published by S. Karger AG, Basel } \\
\text { www.karger.com/crg }\end{array}$ \\
\hline
\end{tabular}

Kamiyama et al.: Unusual False-Positive Mesenteric Lymph Nodes Detected by PET/CT in a Metastatic Survey of Lung Cancer
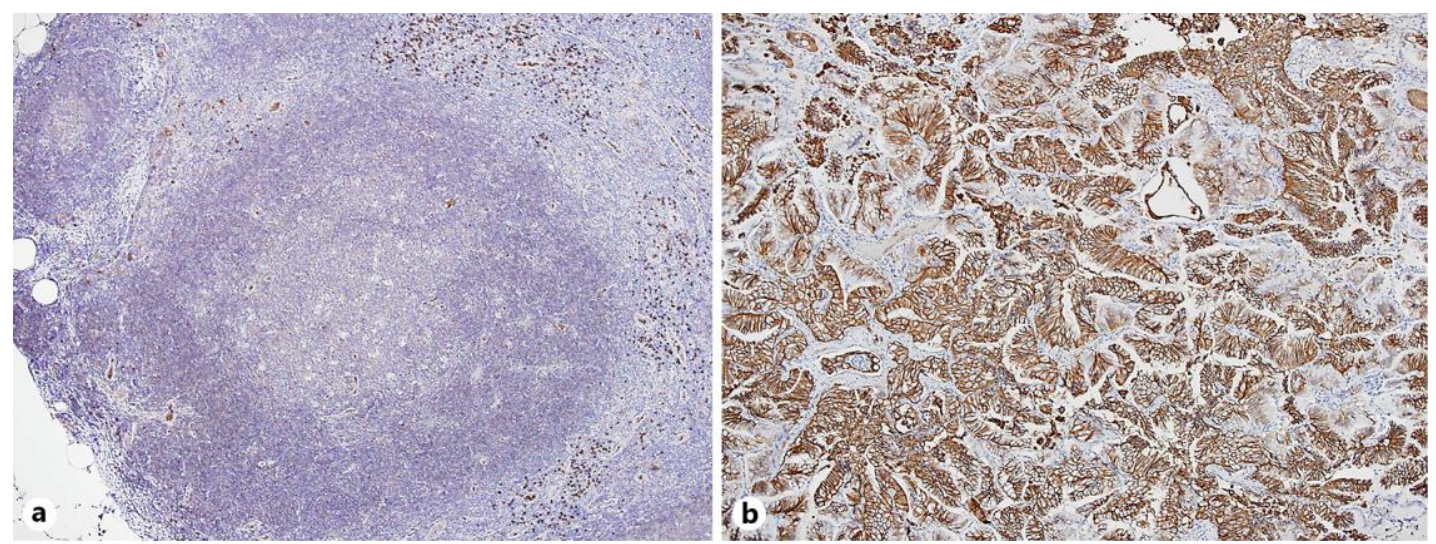

Fig. 5. Glut1 immunostaining of a mesenteric lymph node (a) and the lung cancer (b), counterstained with $\mathrm{HE}$ and presented at a magnitude of $\times 10$ showing partial positivity with low intensity only in the lymphoid follicles (a) and positivity with high intensity in the bronchioloalveolar carcinoma of the lung (b). The protocols for Glut1 immunostaining is described by Chung et al. [9]. 